\title{
3. Ian Castles: Scholar as Truth Teller
}

\author{
William Coleman
}

Ian Castles possessed a rare suite of talents. Not many people have the requisites to become successful agency heads. Only a few of those will succeed in careers of public advocacy after their formal retirement. And still fewer will additionally contribute to scholarship. Castles did all three.

This chapter shines a light on the scholarly dimension of Castles by examining his 1984 paper 'Economics and Anti-Economics' ${ }^{1}$ This paper is equally remarkable and neglected. It is neglected: until this volume was published the paper was almost impossible to obtain. And it is remarkable: we may wonder how could a senior public servant, engrossed in the cares of administration, produce an incisive tract begotten by the careful scrutiny of recondite texts?

The subject of 'Economics and Anti-Economics' is the so-called 'moral critics of political economy' of the nineteenth century. Castles' thesis is that that these men were, in truth, immoral critics of political economy. Indeed, in reading Castles paper, I wonder if even 'immoral' is an understatement; 'appalling, atrocious, indecent to the point of villainy' might be a truer indictment.

Castles' case for his judgement is a careful 30,000 word long examination of the actual; what was actually said by the economists, as distinct from what they were said to have said. And of what was actually believed by anti-economists. In detailing the gulf between these two actuals, Castles' paper amounts to a crushing piece of table-turning upon these supposed 'moral critics' of political economy.

But for all its brilliance 'Economics and Anti-Economics' surely did not succeed in all the ways that Castles may have hoped it would. This chapter seeks to capture in a few strokes the character of Castle's paper, to speculate on its origin, and to ponder its fate.

\section{The character of Castles' paper}

At the very outset Castles groups his protagonists. On one side Castles places the 'economists'; by which he means the classical economists. On the other side are 'anti-economists'. These include ST Coleridge, Thomas Carlyle and

1 Another scholarly interest of Castles lay in the Australian sojourn of WS Jevons. One fruit of this is a display in the Power House Museum devoted to Jevons. 
John Ruskin. These are sometimes known to historians of ideas as the 'sages' of nineteenth century Britain, but could be better described as the rhapsodists, the Savonarolas, the berserks of that society: three men who, over two generations, personified a blazing seam of social and political reaction in British intellectual life; and exhaled cyanide gas against the 'dismal science', as Carlyle so enduringly branded it.

But, critically, Castles adds to his enumeration of 'anti-economists' a second trio of persons; very different in character and station from the first but who, under the mantle of progressivism, broadcast in the twentieth century the same travesty of economics promulgated by reactionaries of the nineteenth. These are three 'teledons' or celebrity intellectuals of the 1960s and 70s; CP Snow, JK Galbraith, and Kenneth Clarke; the authors of The Two Cultures and the Scientific Revolution; The Age of Uncertainty; and Civilisation: A Personal View, respectively.

The case against classical economics which these three disseminate amounted to insinuating a responsibility of classical economics for the banes of nineteenth century 'industrialism': the Dark Satanic Mills, 'the condition of the working class', poverty amidst plenty, the Poor House vs Ascott House. The classical economists, at the very least, bestowed a self-satisfied benediction on this awfulness. They were therefore culpable of moral delinquency; or 'inhuman[ity]' in the words of Kenneth Clark, the art critic who Castles rightly identifies as the leading twentieth century disciple of Ruskin's 'devastating ${ }^{2}$ anti-economics.

Ian Castles contends that the truth about the economists and the anti-economists is much closer to the very opposite: that classical economists possessed a feeling of humanity, and a sympathy for it; while it was the anti-economists who were gripped by a loathing for much of their fellow species.

Castles sustains that claim by contrasting the positions of the two groups on various heads of social and economic policy of the day. Let me go through them.

\section{Education}

Castles points out that 'probably the first serious proposal ever' for universal [publicly funded] education' was made by Adam Smith, in the Wealth of Nations. ${ }^{3}$ In his lead on education Smith was followed by virtually every political economist. By contrast, Coleridge was roughly contemptuous of such programs of universal education, and Ruskin maintained it was best if not all children were required to learn to read.

2 Clark's judgement, taken from Clark (1950).

3 Barthelemi-Gabriel Rolland is recorded by historians of education to be the author, in 1768, of the very first such proposal (see Coleman: 2004: 257). 


\section{Ireland}

Castles bears evidence of a leniency of the classical economists to perpetually troubled Ireland. Ricardo recommended that to Ireland be applied a 'system, of kindness, indulgence and conciliation'. And Nassau Senior, no soft touch in these matters, contended that 'the erection, regulation and support of fever hospitals, infirmaries and dispensaries [in Ireland] should be fully and immediately attended to' (Senior: 1831). ${ }^{4}$ It was the anti-economists who, as Castles documents, felt an irritated, resentful impatience at such solicitation for Ireland's wants, and repeatedly insisted that the Lord would provide whatever necessaries Ireland might require. ${ }^{5}$

\section{The New Poor Law}

The 'New' Poor Law of 1834 provides one of the landmarks of the Dickensian vision of the Industrial Revolution.

But however severe the New Poor Law, it needs to be registered that it was the express position of Political Economists who favoured the Law (such as JS Mill) that the Law was warranted by an obligation of society to relieve the destitution of the destitute. However qualified that obligation was in the minds of Mill and the like, they held that the destitute had a rightful claim on society, and the New Poor Law was to meet that claim. ${ }^{6}$ If they significantly underestimated the size of that claim, it does well to keep in mind that no country in the world (of comparable size) at the time had a national (i.e. state) based system of assistance that the Poor Law provided. Indeed, the political economists most associated with the Poor Law were convinced that it was the relief provided by that Law that had preserved Great Britain in 1848 from the revolution suffered by France, which had no such law (see Senior: 1872).

Political Economists could also be friends of private charity, and the greatest of them was the greatest friend: Ricardo. On his estate Ricardo established a dispensary, an alms house, and a school; he was a prolific subscriber to various charities: for example, the Poor of the Parish of Hanovers Square, Extreme Distress at Spitalsfield and Persons Confined for Small Debts (the list is extensive).

\footnotetext{
4 James McCulloch, the Ricardian economist, believed that in Ireland 'the poor should have a claim, a right to support'. Senior opposed any right to such a claim (Senior: 1831: 30).

5 'What are the great causes of Irish misery?' asked John Wilson (anti-economist and friend of ST Coleridge) ... Without hesitation we reply ... he is the author of his own misery ... in the qualities of disposition for national prosperity, he stands at the lowest of civilised men' (see Castles: 1984: 34).

6 Some of the more obnoxious provisions of the administration of these Laws - such as the enforcement of silence during the meals of the inmates of the workhouses - were the coinage of Edwin Chadwick, and bespeak a rationalist confidence in the power of social design that is alien to political economy. I venture no such specific measures were recommended by any political economist of significance.
} 
As Castles stresses, it was Carlyle who considered all this provision for the poor (be it public or private) an absurdity.

Why not regiment these unfortunate wretches, put colonels and corporals over them and thrash them, if it proved needful, into habits of industry ... Try them for a couple of years and if they could not feed themselves ... they ought to be put out into the world' ... Sell them in Brazil as niggers.

\section{Slavery}

Smith, Ricardo, Mill, Senior, were strenuous anti-slavers. The anti-economists, by contrast, were almost always slavers.

Coleridge snarled that the Empire was being subverted by abolitionism. In Unto This Last - the frenzy anti-economics so praised by Clarke - Ruskin announced that slavery is 'an inherent, natural and eternal inheritance of much of the human race. It was Carlyle's fury at abolitionism that was the very occasion of his coinage the 'Dismal Science'; in his paper the 'Nigger Question' of 1849, amidst fantasies of firing squads for political economists, he champions slavery as 'the answer' to that 'question'.

There is an historical epilogue here: 'the Eyre Controversy'. In October 1865 a rioting mob in Jamaica killed 18 people. At the behest of the Governor, Edward James Eyre, British troops executed, or lawlessly killed, 586 blacks, and flogged another six hundred. Scandalised, JS Mill formed a Jamaica Committee to bring Eyre to account. But Carlyle felt 'heartily sorry for Eyre', and with Ruskin formed an Eyre Defence Committee to rebut the 'nigger philanthropists' of Mill and Henry Fawcett.

Let me pause to insert a speculation. I put to you that all three of these 'moral critics' of political economy adopted - presumably as a model for British public - the persona of tyrant. In the conduct of Eyre we have sinister possibility of Life imitating Art. Thus there is a more than personal significance in the character - the bad character - of the anti-economists; and there is a broader significance in the good character of Ricardo and Malthus. The evidence on that score, that Ian Castles carefully plots, is that these most vilified of men were equable, amicable, and affectionate.

Castles also assembles a fund of personal testimony as to the intellectual honesty of the classical economists. This evidence, too, has a broader significance. For the insinuation of JK Galbraith in the Age of Uncertainty is that the classical economists were not so. Certainly, Galbraith's implicit message is that the only significance in their thought lies in whatever propaganda purpose to 
which it might be put. Galbraith's imputation of logical insignificance to the theories of classical economics is doubtless rooted in the position (so congenial to the adversaries of classical economics) that reality is plastic; that it can be pushed into any desired shape; that we have a kind of play-doh economy free of constraints, trade-offs, costs etc. The upshot of this line of thinking is that there is no hidden mechanism to trouble over, there is no economic law to be uncovered; only political power to be obtained

Very different was the outlook of the political economists: they believed that a powerful but complex mechanism underlay economic events; a mechanism that was hidden from a careless observer but yet could be found. It was on account of this outlook that, as Maria Edgeworth records, '[Ricardo and Malthus] hunted in search of truth and huzzaed wherever they found her ...'. I suspect it was partly that naïve sense of discovery that impelled Ricardo to unabashedly advance his doctrines in the form of motions to the House of Commons, that were lost by vast majorities; provoking even one of his parliamentary allies to rise from the bench and declare that the Member for Portarlington must have 'descended from Jupiter'.

How unworldly the 'worldly philosophers' seem in contrast to Clark, Galbraith and Snow, those three sleek greyhounds of various mid-twentieth century 'corridors of power'. The ambassador's residence, the division lobby of the House of Lords, the weekend party at Windsor castle: such were their natural habitats.

And it is on account of their unworldliness that the classical economists were very differently motivated to write than Galbraith, etc. On this difference Castles tellingly quotes Galbraith from his Affluent Society:

Audiences of all kinds applaud what they like best ... the great television and radio commentators make a profession of ... saying with elegance and unction what their audience[s] find most acceptable.

Indeed.

The conflict between the wish to be something in the world and the wish for other things brings me to Castles' treatment of CP Snow.

What provokes Castle's ire in Snow's Two Cultures is Snow's light-minded pairing - in a single phrase - of Napoleon with Adam Smith. One might give some quarter to Snow for this apparent fatuity; was Snow as a self-identified 'democratic socialist' seeking some epitomisation of 'autocratic capitalism' and in failing to find one settled for epitomisation of autocracy (Napoleon) and epitomisation of capitalism (Smith)? But, however that may be, Castles does not hesitate to pounce, and stresses the perfect antipathy between the world views 
of the Emperor and the professor; the one with a philosophy of conquest, and the other a philosophy of exchange; an antithesis exemplified in their stance to empire: the one the supreme imperialist, the other an emphatic anti-imperialist, who saw empire as corrupt and based on costly methods of Mercantilism, and who would have found every corroboration for this thesis in the 'Continental System' introduced by Napoleon. This last policy provoked some forward opposition by some economists in France, which Napoleon dismissed as 'the twaddle of economists'. As T B McCauley said, Napoleon 'hated political economy'.

We can detect in the Napoleonic Empire a prefiguring of the totalitarian state. We see it, among other places, in Napoleon's sensitivity to (and anxiety about) social ideas, including economic ideas. Napoleon once complained if there were a monarchy made of granite, the abstractions of the economists would be enough to grind it into dust. Napoleon was resolved to subvert any such subversion by abstract thought: thus J-B Say, having refused the importunate overtures of the Emperor, was dismissed from the Legislature, and publication of his Treatise of Political Economy forbidden; thus Napoleon abolished the Institut concerned with social sciences, amidst much fuming about 'ideologists' (while preserving the Institut of natural sciences and humanities).

Warp it, break it; make it teach that black is white. This is how totalitarian societies deal with social thought. War is Peace, Freedom is Slavery, Ignorance is Strength.

In 'Economics and Anti-Economics', written in 1984, Castles makes effective rhetorical reference to Orwellian oxymorons to underline the perverse rewriting of history of economics by Clark and Galbraith. 'Inhumanity is Humanity' is the double-speak slogan under which they stand. And yet Castles' references to Orwell's 1984 in some respects miss the mark. For we don't live in a totalitarian state; and the perversely false mythologies of Clark and Galbraith flourish without the terroristic negative incentives of such a state. A free society evidently contains positive incentives that powerfully nourish such mythologies. Pondering what those positive incentives are brings me back to the unwitting (or shameless) admission of Galbraith that Castles highlighted:

Commentators make a profession of saying with elegance and unction what their audience[s] find most acceptable.

The looming reference is the corruption to thought that lies in the temptations to celebrity. To put the reference another way, unpopularity and obscurity can be a price of integrity. An indifference to those prices can be a source of integrity.

Gladly, considerations of celebrity did not figure in Ian Castles' motivations to write 'Economics and Anti-Economics'. It was not his lot to deliver his economics 
by Reith Lecture; he did not have a BBC microphone or camera. Instead he gave his paper to a session in Canberra of the (soon to expire) ANZAAS Conference; no place at all for any 'great radio and television commentator'. Ian Castles had the worldly unworldliness of Ricardo, and regardless of the presence or absence of the television camera, he 'hunted in search of truth and huzzaed wherever he found her'.

\section{Castles' audience then and now}

Yet perhaps we should also regret Castles' apparent unconcern about the size of his audience. For I am conscious that Ian's apparently vanquishing riposte to anti-economics appeared not long before an eruption of anti-economics in Australia of which in its ignorance, frenzy and indecency would almost match that of the nineteenth century originals (see Coleman and Hagger: 2001 for an account of this episode).

The proximity of Castles paper to the eruption of anti-economics also invites questions about what occasioned Castles, then secretary of the Department of Finance, to devote considerable hours to making such a foray. ${ }^{7}$

Perhaps a clue lies in the fact that in 1984 Australia had a new government, the Hawke Labor government. The earlier Whitlam Labor government had, of course, experienced tortured relations with Treasury and the Reserve Bank. The apparent tension between 'economists' and Labor were reinforced by the almost simultaneous collapse of the Keynesian consensus, and the cordial reception by Thatcher and Reagan of the monetarism of Milton Friedman. The potential for a renewed division with 'economists' on one side and 'labour' on the other was brought out by Friedman's 1981 visit to Canberra. This concluded with a dinner with a group of Labor members including what Friedman classified as 'real socialists'. In this 'acrimonious' encounter, Friedman later recalled, Bob Hawke 'made a long and involved statement out of which I could make neither hide nor hair' (Friedman and Friedman: 1999: 432).

In 1984 the new Hawke government was finding its way towards a program of deregulation and privatisation, and Hawke himself had excellent relations with his chief economic advisor, Ross Garnaut. But was it not also true that Hawke had a history of a conflicted response to economics? He had majored in economics in his undergraduate degree, but in Oxford his undertaking to complete a dissertation under the rubric of economics was derailed by an

7 He is recalled in this period as a visitor the National Library of Australia. Doubtless he became acquainted with its valuable records of political tracts in his employment in the archives division of the National Library in the mid 1950s. 
'almighty row' with his supervisor, Colin Clarke, who was disdainful of Hawkes 'ability with economics'. For all that, Hawke formed on his return to Australia an 'inseparable trio' with two economists Max Newton and Ron Hieser, and an ANU professor of economics, Horrie Brown, became his 'mentor'. It was through Brown that Hawke gained an introduction to the ACTU, which employed him from 1957. But in 1950s 'national wage cases' economics seemed to be the possession of employers. Their counsel was Sir Richard Eggleston who had a 'knowledge of economics ... unique in the [legal] profession', and he would call economists as witnesses. But Hawke had the economists Wilfred Salter and Eric Russell coach him in the economics of index numbers. He successfully called DB Copland as a favourable witness, and successfully daunted JON Perkins, later a professor of economics, into withdrawing as witness for employers. All in all, the encounter of Hawke with economists was a chequered one.And in 1984 Hawke was Prime Minister. Was Castles paper an attempt to replace the motif of 'economists versus socialism' with 'economists versus reaction'? Possibly. What is certain is that the paper did not prevent that eruption of anti-economics that followed from around 1990; we may suspect it did little to temper its frenzy. During that ghastly episode Castles paper would have given some heart to the few who knew of it. ${ }^{8}$ But by its nature it could not supply the logical tools that might provide a logical antidote to the distemper. For while Castles paper is a tour de force, the very source of its force also constitutes a frailty: its ad hominem aspect. When I say ad hominem I need hardly say that Castles does not proceed by denigrating the personal attributes of his targets; he did not describe any of them as an 'ill-bred, half witted Scotchman with a damned soul'; that is John Ruskin's own well-bred caption for Adam Smith. When I say ad hominem I mean that Castles' strategy is to show that the positive positions of anti-economists were ignorant and ludicrous, and their normative positions were sometimes abhorrent. There is both a strength in this, and a frailty: for to show that someone has misrepresented (besmirched, calumnied) a corps of doctrine is clearly not to show the doctrine is true, or even an advance towards truth. And to demonstrate that the persons who have censured some tendency are far more censurable themselves, is not to demonstrate the tendency itself is beyond any censure. Thus while Castles' paper establishes that the 'moral critics' offended justice, it leaves unidentified, unexamined and unresolved the issues that were the background of that act of injustice. And his method of 'personal critique' leaves open a method of 'personal defence'; whereby the modern day anti-economist sheds the burden of their predecessors' follies with the remark, 'we all know that Ruskin was barking mad, but still...'.

8 Peter Walsh, the Minister of Finance 1984-1990, knew and appreciated the paper. In the mid 1990s the Secretary of the Australian Department of Housing and Regional Development distributed it amongst senior people in the department. 'My impression was that the minister [Brian Howe] and his advisers (then including Jenny Macklin) were a bit bemused, perhaps even wary of what this might mean given their emphasis on planning and government intervention!' (Communication to author). 
But to say Castles' paper left 'unresolved the issues' is only to say he left unresolved what no one else has yet resolved. What he did do in 'Economics and Anti-Economics' is to use the scholar's pen to slay a mythology; and not a harmless mythology but one that has been an adversary of improvement. Ian Castles the scholar was at one with Ian Castles the servant of the public.

\section{References}

Castles, Ian (1984). 'Economics and Anti-Economics', 54 ${ }^{\text {th }}$ ANZAAS Congress, 18 May 1984.

Clark, Kenneth (1950). The Gothic Revival: an Essay in the History of Taste, London, Constable.

Coleman, William (2004). Economics and Its Enemies: Two Centuries of AntiEconomics, Palgrave Macmillan.

Coleman, William and Alf Hagger (2001). Exasperating Calculators: the Rage Against Economic Rationalism and the Campaign against Australian Economists, Macleay Press.

D’Alpuget, Blanche (1982) . Robert J Hawke, a biography, Lansdowne Press.

Friedman, Milton and Rose D (1999). Two Lucky People. Memoirs, Chicago: University of Chicago Press.

Senior, Nassau (1831). Letter to Lord Howick on a Legal Provision for the Irish Poor.

Senior, Nassau (1872). Correspondence and Conversations of Alexis de Tocqueville with Nassua William Senior From 1834 to 1859, London: Henry S King. 